\title{
Influence of Women Empowerment on Adoption of Agroforestry Technologies to Counter Climate Change and Variability in Semi-Arid Makueni County, Kenya
}

\author{
Kalovoto Damariis M, Kimiti Jacinta M and Manono Bonface $\mathbf{0}$ \\ Department of Environmental Science and Land Resources Management, South Eastern Kenya University, Kenya
}

Submission: March 24, 2020; Published: April 13, 2020

*Corresponding author: Kalovoto Damaris M, Department of Environmental Science and Land Resources Management, South Eastern Kenya University, Kenya

\section{Abstract}

Climate change has become a major concern in Africa, where many climate models predict that it will cause among other things; decreasing rainfall especially in arid areas, warmer temperatures and increasing severity and frequency of extreme weather events. Subsistence farmers in developing world are unable to cope with such climate variability since they do not have the capital to invest in new adaptive practices. They are also especially sensitive to climate change since they rely almost entirely on rain- fed agriculture. This study was carried out at Nguumo and Makindu locations in Makindu sub-county, Makueni County. The main objective of the study was to examine the role of women in agroforestry technologies as an adaptation strategy to climate change and variability in Makindu and Nguumo locations, Makindu sub county, Makueni County, Kenya. Information was gathered using Semi- structured questionnaires which had some fixed/closed and open ended questions. Answers for these questions were gathered through in-depth interviews with respondents, visiting various focused groups and obtaining their views through discussions and also observations on various farms. Information was generally gathered from both men and women without necessary targeting the women alone to avoid biased answers. For example women may feel that they carry most of household chores, therefore ignore the participation of men. Linear regression analysis done to investigate the degree to which women empowerment in and access to agroforestry technologies help in adapting to climate change and variability was fitted for both locations. Results obtained indicated that there was a positive and a significant relationship between women empowerment and agroforestry technologies $(\mathrm{p}<0.05)$ in Makindu Location and Nguumo Location. For the empowerment coefficient in Women for Makindu location and increment in women empowerment by one unit increases the adoption rate by 0.432 units. For the coefficient in Nguumo location an increment of women empowerment by one unit increases the adoption of agroforestry by 0.232 units. The study recommended enhancement of women capacity to make decisions, access resources equitably and benefit from development initiatives like agroforestry. The Study concluded that empowering women in their challenges is very critical in women adoption of agroforestry technologies.

Keywords: Women empowerment; Agroforestry technologies; Climate change

\section{Introduction}

Since the 1995 women's conference in Beijing, donors, policy makers and development practitioners have pointed out the critical role of gender in development programs [1-7]. There is a general consensus that gender inequalities in areas such as ownership and access to resources, land tenure systems, education, extension and social-cultural factors have contributed to lower agricultural productivity and higher poverty levels [8]. However, due to their generally weak position in society and family, women are usually not included in discussions and decision-making processes related to climate change or any other issue. Their limited access to information and resources such as land and credit further prevents them from developing their capacities in agriculture although they play a crucial role in food security and agroforestry. In addition, there is a gender-related bias regarding the value and usefulness of local knowledge. Women often feel ignored, overlooked and not taken seriously when they try to make their contributions and share their knowledge [9]. They are seen as 'farmwives' rather than true farmers, and as such as not capable of producing and sharing valuable knowledge about farming. Society ignores the value of indigenous knowledge by continuing to view 
the knowledge and practices of women as 'primitive', unscientific and as a hindrance to development. The male members of the families think that if they use this unscientific knowledge promoted by the women, they cannot get more crops from the land. Men only believe in the usefulness of local knowledge if it is confirmed by a scientist or agricultural officer. Only then will they accept it as environmentally and socially appropriate and hence more sustainable.

African women play an important role in production as portrayed by Esther Boserup (Agricultural economist) in her book on Women's Role in Economic Development [10]. Boserup used research data from Africa, Asia, and America to highlight women's central positions in economic life of their communities. Together with [5,6,11-15] reports important prepositions which highlight the importance of focus on agroforestry and women as women play a key role in most production systems, women contribution to food security is made in the face of great obstacles, women contribute substantially in production but there is systemic exclusion from benefits associated with technological change, given access to same resources as men (education, farm inputs, labour) food production will be increased from $10-20 \%$, and finally though women play a key role their contribution to agriculture is largely ignored by policy makers [16].

Although men and women are both involved in management of trees planted on farms, earlier literature confirms the fact that women do most of the work, especially at the initial stages of tree establishment [17]. For example studies conducted by [18] in Tanzania and [19] in Zimbabwe, established that over $60 \%$ of Tanzania women are responsible for managing tree species planted on farms while over $80 \%$ of Zimbabwean women are responsible for watering young seedlings. This findings were confirmed in a study by [20] that determined the adoption of fodder in the central highlands of Kenya. Despite the fact that $91 \%$ of household respondents were male headed, $89 \%$ of these households females were responsible for managing fodder. A similar scenario was observed in Uganda [21] whereby over $80 \%$ of households with calliandra, women were involved in management. The present study therefore examines the influence of women empowerment in and access to adoption of Agroforestry technologies to counter climate change and variability in Makindu and Nguumo locations.

\section{Methodology}

\section{Study area, location and settlement history}

The study area lies in Makueni County which covers an area of $8034.7 \mathrm{~km}^{2}$. The county boarders Kajiado to the west, Taita Taveta to the south, Kitui to the east and Machakos to the north. The county is currently divided into nine sub counties namely Makueni, Mukaa, Kilungu, Kibwezi, Kathozweni, Makindu, Mbooni (East, West) and Nzaui. Makindu Sub County is the target study area. It has three divisions Makindu, Tsavo West National Park, Chyulu Game Reserve), four locations and fifteen sub-locations Figure 1 show maps of the two locations and their sub locations. The study sites are Makindu and Nguumo locations in Makindu Sub County which covers four locations and fifteen sub- locations. Nguumo location has four sub locations namely Syumile, Muuni, Ndovoini, Kaunguni. Makindu location has five sub locations which are: Kiu, Manyatta, Kisingo, Kamboo, and Kai [22]. This is because the other two division are game reserves and no agricultural activity takes place.



Figure 1: Map showing Nguumo and Makindu locations.

Source: Chief's offices Nguumo and Makindu locations. 
The choice of these two locations (Nguumo and Makindu) was influenced by the evident severe effects of climate change and the active participation of locals in agroforestry practices as an effort to adapt and cope with climate change. Also, there is reliable little rainfall in the area coupled with some reliable sources of water like boreholes, wells and dams which can provide some water for irrigation purposes more so; records from [23] showed that these two locations were active in crop and livestock farming despite the challenges of climate change and variability.

Nguumo and Makindu locations have total population of 11571 households. Nguumo location has 5774 households while Makindu location has 5797 households [24]. $90 \%$ of the population is rural based. Livestock production and crop farming are the back bone of the people's economy in the area contributing to nearly three quarters of household earnings [25]. Livestock species kept include Cattle, sheep and goats are the most important animals in the area [26]. Crops such as maize, beans, sorghum, pigeon peas, millet and cassava are cultivated mainly for subsistence while green grams, sweet potatoes, vegetables and fruits (like mangoes, melons and bananas) are grown for sale [26]. Makindu Sub County was first settled in the early 20th century by railway construction workers. It acted as a base for railway construction workers on the Mombasa Kampala railway project by that time. With time, many people have settled in the area from different parts of the country like Machakos, Kitui, Makueni and others [23]. The Sikh temple in Makindu built at that time, still bears reminiscence to the railway building days. The temple was a place of worship and social centre for many of the workers from India. The temple is well preserved and is managed as a free lodge for any traveller who knocks on its door. Makindu division is also served by Makindu airport [27].

\section{Data collection and analysis}

Primary data was collected using various qualitative and quantitative methods. Primary data included information gathered directly from respondents/inhabitants of the area through semi- structured questionnaires which had some fixed/ closed and open ended questions. Answers for these questions were gathered through in-depth interviews with respondents, visiting various focused groups and obtaining their views through discussions and also observations on various farms. Information was generally gathered from both men and women without necessary targeting the women alone to avoid biased answers. For example women may feel that they carry most of household chores, therefore ignore the participation of men.

This method was used to access women participation in agroforestry technologies as an adaptation measures to climate change and variability in the area. Secondary data was obtained from published material and internal sources; journals, books, annual reports, workshop proceedings and periodicals, relevant literature from libraries and internet and Ministry of Agriculture. Primary data was collected using various qualitative and quantitative methods. Primary data included information gathered directly from respondents/inhabitants of the area through semi- structured questionnaires which had some fixed/ closed and open ended questions. Answers for these questions were gathered through in-depth interviews with respondents, visiting various focused groups and obtaining their views through discussions and also observations on various farms. Information was generally gathered from both men and women without necessary targeting the women alone to avoid biased answers. For example women may feel that they carry most of household chores, therefore ignore the participation of men.

Study generated qualitative and quantitative data from the administered questionnaires. Qualitative data was subjected to indepth analysis and used to compliment discussion of the analysed quantitative data. The Quantitative data was cleaned, sorted, summarized and stored using Ms Excel and statistical package for social sciences (SPSS). Quantitative and qualitative data were summarized and presented in forms of charts, tables, frequencies, graphs and percentages where necessary. Both descriptive and inferential statistics were used to analyse the qualitative and quantitative data. In inferential statistics, correlation analysis and linear regression analysis were used. In descriptive statistics charts, graphs, mean, percentages and frequencies were used.

\section{Results and Discussion}

\section{Proportions of households practicing agroforestry in Nguumo and Makindu Locations}

The study sought to investigate whether the respondents practiced agroforestry. Out of those who practiced agroforestry in the selected study sites majority were females. Nguumo location led in number of females, $40.35 \%$ practicing agroforestry followed by Makindu location with $28.07 \%$ females. Males in Nguumo and Makindu were $32.0 \%, 18.0 \%$ respectively. This clearly indicated that more women are involved in agroforestry practices than men in the two locations. (Figure 2) The current trend of the results is in agreement with the findings by [28] who argued that female headed households were more likely to take up climate change adaptation options when they are exposed to information than male headed because they have more access to land.

From the results in figure 2 , it can also be deduced that majority of the women in the two locations were aware of most of the agroforestry technologies practiced in several parts of the world as an adaptation to climate change and variability and were practicing them. These results are in agreement with the findings by [29] who indicated that agroforestry is a long-established farming practice in many parts of the world for livelihood diversification and climate change adaptation. 


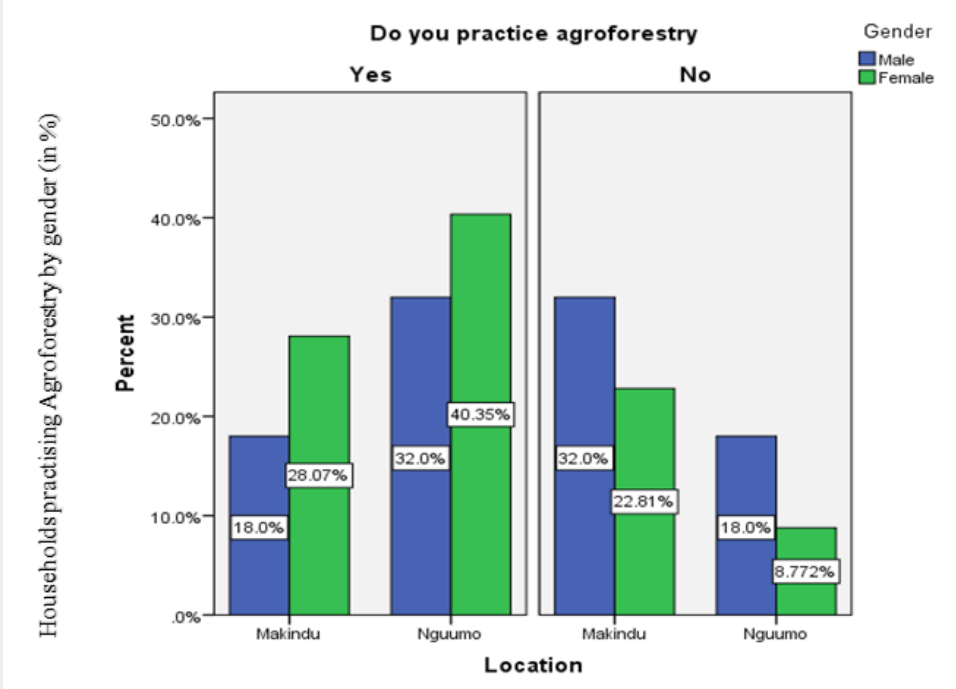

Figure 2 Proportions of household practicing agroforestry (\%) by gender in Nguumo and Makindu locations.

Proportions of households practicing tree planting and livestock keeping in Nguumo and Makindu locations

Table 1: Proportions of households by gender planting trees and keeping livestock (\%) in Nguumo and Makindu locations.

\begin{tabular}{|c|c|c|c|c|}
\hline \multirow{2}{*}{ Sub-location } & \multicolumn{2}{|c|}{ Tree planting } & \multicolumn{2}{c|}{ Livestock keeping } \\
\cline { 2 - 5 } & Male \% & Female in charge \% & Male \% & Female in charge \% \\
\hline Nguumo & 42.3 & 57.7 & 42.4 & 57.6 \\
\hline Makindu & 28.2 & 71.8 & 47.1 & 52.9 \\
\hline Overall mean & 35.25 & 64.75 & 44.75 & 55.25 \\
\hline
\end{tabular}

The agroforestry technologies practiced by women in Makindu and Nguumo locations included whether the farmers plant trees, whether they grow crops, pastures and fodder crops and whether they kept livestock. Results presented in Table 1 indicated that in Makindu location, 28.2\% of males, $71.8 \%$ females planted trees and $47.1 \%$ males, $52.9 \%$ females kept livestock. In Nguumo location, $42.3 \%$ males, $57.7 \%$ females planted trees while $42.4 \%$ males and $57.6 \%$ females kept livestock. Majority of the respondents who planted trees and kept livestock in both locations were females (Table 1).

A chi-square test of independence was calculated comparing the frequencies of households planting trees and gender in Nguumo and Makindu locations. A significant interaction was found $\left(X^{2}(1)=49.05, \mathrm{p}<0.05\right)$. Women were more involved in planting trees in both Nguumo and Makindu locations.

A chi-square test of independence was also calculated comparing the frequencies of households keeping livestock and gender in Nguumo and Makindu locations. A significant interaction was found $\left(X^{2}(1)=38.97, \mathrm{p}<0.05\right)$. Women were more involved in keeping livestock in both Nguumo and Makindu locations.
Combination of these activities on the same piece of land maximizes the returns from the land with or without the use of sophisticated technology [30]. This intercropping solved the problem of food, fuel wood, timber shortage and conserved soil moisture contents, also ameliorated the harsh climatic condition. This collaborates with the findings of [31] who indicated that agroforestry contributes to soil and water conservation besides improving fertility. The multipurpose woody perennials provide livestock fodder or function as living fences around the grazing land or provide shade /browse and also provide fruits. [32] added that silvipastoral as asset of land system involves the deliberate combination of woody perennials, animals, crops on the same management unit. Under this technology, improved pasture species are grown along with tree species. Fodder and pastures were grown for livestock feeding purposes.

This was also confirmed by the findings of [33] who indicated that in Tanzaniathe Chagga farmers were self-sufficient in fodder produced primarily from the trees and shrubs grown in home gardens. In addition, [34] confirmed this by indicating that in Nambale division of Busia district (Kenya) farmers had planted Sesbania sesban on terraces to control soil erosion, females were 
provided with fuel wood, green manure and fodder.

\section{Role of gender in Agroforestry adoption and its adaption to climate change}

As indicated in the Table 2 majority of females in both locations indicated that gender plays a big role in agroforestry adoption in Makindu location, overall average was $30.5 \%$ males, $69.5 \%$ females and Nguumo $32.8 \%$ males, $67.2 \%$ females stated that gender plays a critical role in agroforestry adoption and adaptation to climate change and variability.

Table 2: Gender role in Agroforestry adoption and adaption to climate change.

\begin{tabular}{|c|c|c|c|c|c|}
\hline \multirow{2}{*}{ Location } & & \multicolumn{2}{|c|}{ Makindu } & \multicolumn{2}{|c|}{ Nguumo } \\
\hline & & Male\% & Female $\%$ & Male\% & Female $\%$ \\
\hline \multirow{4}{*}{ Role played } & Planting & 30.5 & 69.5 & 39.1 & 60.9 \\
\hline & Cultivating the land & 44.4 & 55.6 & 47 & 53 \\
\hline & Watering young seedlings & 34.6 & 65.4 & 30.6 & 69.4 \\
\hline & Harvesting & 12.5 & 87.5 & 14.5 & 85.5 \\
\hline Overall average & & 30.5 & 69.5 & 32.8 & 67.2 \\
\hline
\end{tabular}

The results revealed that men and women play different roles in dealing with climate change where women are the major actors in several areas of adaptation (agents of change). Therefore, the role of women in agroforestry technologies as adaptation measures to climate change effects should not be under-estimated [35]. [36] concurs with the findings who indicated that women is one of the most vulnerable part to the impacts of climate change and are actually the one who have a lot of roles and initiatives to play in various crises and the negative impact of climate change. Women are more involved in agroforestry technologies/ activities as an adaptation strategy as confirmed by the findings of [37]. In Makindu and Nguumo locations the study established that women have taken part in almost all production activities related to agricultural production like land preparation, planting, weeding, watering, harvesting but men are the ones who decide on whether to sell the product or not (dominate the marketing of the product). These results are in consonance with the findings of [38] who indicated that women contribute more hours of labour to cultivation, livestock raising and tree management and highly involved in activities like nursery tending and seed preparation.

\section{Ability of women to manage agroforestry in Makindu and Nguumo locations.}

As indicated in Figure 3 in Makindu location 47.2\% females, $52.8 \%$ males and in Nguumo location, 46\% females, and 54\% males indicated that women were able to manage agroforestry. The results confirmed that women had the ability to manage agroforestry given the opportunity.



Figure 3: Ability of women to manage agroforestry in Makindu and Nguumo locations. 
The results from figure 3 confirmed that women had the ability to manage agroforestry despite the barriers they face.

This concurs with the findings of [39] who indicated that women farmers form an integral part of agroforestry, as they were often responsible for managing trees especially at the early stages of establishment because men consider this feminine work. Also women are known to be principal holders of knowledge and managers of traditional home gardens, and make up about $60 \%$ of the practitioners of innovative agroforestry practices such as domestication of indigenous fruit trees and production of dairy fodder.

The current study revealed that an overwhelming majority of women in both Makindu and Nguumo locations were able to manage agroforestry technology in response to climate change effects. The results concurs with findings from a similar study by [16] which indicated that women play important roles in all agriculture and forestry activities, including management and utilization of natural resources and their protection, as was also confirmed by [40].

Also the results revealed that women in Nguumo and Makindu locations were highly involved in agroforestry technologies because they were usually responsible for providing the family with its food and also helped add the family income by farming because they could sell minor products like fruits, milk, vegetables from agroforestry and get income (called farmer women). This was in line with the findings of [36] who established that women (farmer women/rural women) had greater burden of climate change impacts than men because they had primary responsibility of collecting water or firewood as well as providing food for their families

\section{Need for women empowerment, areas of women empowerment and women empowered in Makindu and Nguumo locations}

The study sought to establish whether women need to be empowered in the areas where they are disadvantaged (challenges) in order to be able to easily access and adopt agroforestry technologies.

From the table 3 below, 83.3\%, Nguumo $87.3 \%$ of women suggested that they needed to be empowered in agroforestry technologies.

The study sought to establish whether women need to be empowered in the areas where they were disadvantaged (challenges) in order to be able to easily access and adopt agroforestry technologies. They suggested that the empowerment could be done through county government, non-governmental institutions and ministry of agriculture (MoA) providing them with loans, provision of more extension workers, training through workshop, shows, visits and seminars, provision of inputs like seeds, pesticides, insecticides, fertilizers and tools.

83.3\% women in Makindu and $87.3 \%$ women in Nguumo suggested that they needed to be empowered in agroforestry technologies (Table 3). In Nguumo location, $67.92 \%$, of women needed to be empowered in land tenure, $75.47 \%$ involvement in decision making, $88.89 \%$ access to resources, and $71.70 \%$ access to extension information. In Makindu location $64.8 \%$ needed empowerment in access to resources, $53.70 \%$ in land tenure, $59.26 \%$ in decision making, and $74.07 \%$ in access to extension information. Only small percentages of women were empowered in the two locations, Nguumo $12.7 \%$, Makindu $16.7 \%$.

Table 3: Need for women empowerment, areas of Women empowerment and women empowered in Makindu and Nguumo locations.

\begin{tabular}{|c|c|c|c|}
\hline \multicolumn{2}{|r|}{ Location } & Nguumo (\%) & Makindu (\%) \\
\hline \multicolumn{2}{|c|}{ In need of empowerment } & 87.3 & 83.3 \\
\hline \multirow{4}{*}{ Areas } & Access to resources & 88.89 & 64.81 \\
\hline & Owning land & 67.92 & 53.7 \\
\hline & Decision making & 75.47 & 59.26 \\
\hline & Access to extension information & 71.7 & 74.07 \\
\hline Empowered & & 12.7 & 16.7 \\
\hline
\end{tabular}

Results in table 3 indicated that only as small percentage of women had been empowered in the two location hence a deficiency in women empowerment (Nguumo 12.7\%, Makindu 16.7\%). 87.3\%, of women in Nguumo location, $83.3 \%$ of women in Makindu, needed empowerment in agroforestry technologies in various areas such as, socio- cultural factors, decision making and access to basic education in order for them to participate fully in agroforestry technologies as an adaptation to climate change. This was confirmed by the findings of [41], [42] who indicated that there were gender-specific risk perceptions and worries about climate change that influence adaptive behaviour which were due to prevailing social inequality and varying susceptibilities.

From the findings of the current study (Table 3) it was clearly indicated that access to information, owning land, decision making and access to resources affect adoption of agroforestry technologies. Lack of access to these services burdens the woman for it is not only the role of woman to produce food for 
the family but also feed livestock and oversee family's nutrition status, thus raising higher worries about declining agricultural productivity and higher incidences of food insecurity. This means that Women's roles in food production are affected when the food production deteriorates due to drought and erratic rainfall exposing households to food security risks as was confirmed by [43].

Also from results of table 3 it is clearly indicated that, insecure land rights, limited access to capital and productive inputs (resources) hindered women of both locations from taking up climate-smart practices such as agroforestry and conservation agriculture [44].

Relationship between Factors influencing adoption of agroforestry technologies by women and women empowerment

The study sought to establish the strength of the relationship between Agroforestry practices by women, empowering women towards adoption of agroforestry, access and implementation of agroforestry information and adoption of agroforestry technologies by women. To achieve this Pearson's correlation coefficient was performed since both the independent and dependent variables are in a ratio scale. There was a positive linear relationship between adoption of agroforestry technologies and empowering women towards adoption of agroforestry (rho = 0.501 , $\mathrm{p}$-value $<0.05$ ). This indicates that a unit change in women empowerment towards adoption of agroforestry increases the adoption of agroforestry by women by $50.1 \%$. Thirdly, there was a significant positive relationship between adoption of agroforestry and access and implementation of agroforestry information by women (rho $=0.630, \mathrm{p}$-value $<0.05$ ). This implies that a unit increase on how women access and implement agroforestry information increases the adoption of agroforestry technologies by women by 63\% [28-36] (Table 4).

Table 4: Correlation Analysis on factors influencing of adoption of agroforestry technologies by women and various independent variables in Makindu and Nguumo locations.

\begin{tabular}{|c|c|c|c|c|c|}
\hline & & $\begin{array}{l}\text { Adoption of Agro- } \\
\text { forestry Technol- } \\
\text { ogies }\end{array}$ & $\begin{array}{c}\text { Agroforestry Practices } \\
\text { by Women }\end{array}$ & $\begin{array}{c}\text { Empowering Women } \\
\text { towards Adoption of Agro- } \\
\text { forestry }\end{array}$ & $\begin{array}{l}\text { Access and Implementation of } \\
\text { Agroforestry Information }\end{array}$ \\
\hline \multirow{3}{*}{$\mathbf{Y}$} & $\begin{array}{l}\text { Pearson Cor- } \\
\text { relation }\end{array}$ & 1 & & & \\
\hline & Sig. (2-tailed) & & & & \\
\hline & $\mathrm{N}$ & 70 & & & \\
\hline \multirow{3}{*}{$\mathrm{X} 1$} & $\begin{array}{l}\text { Pearson Cor- } \\
\text { relation }\end{array}$ & $.627^{* *}$ & 1 & & \\
\hline & Sig. (2-tailed) & 0 & & & \\
\hline & $\mathrm{N}$ & 70 & 70 & & \\
\hline \multirow{3}{*}{$\mathrm{X} 2$} & $\begin{array}{l}\text { Pearson Cor- } \\
\text { relation }\end{array}$ & $.501^{* *}$ & $.370^{* *}$ & 1 & \\
\hline & Sig. (2-tailed) & 0 & 0.002 & & \\
\hline & $\mathrm{N}$ & 70 & 70 & 70 & \\
\hline \multirow{3}{*}{$\mathrm{X} 3$} & $\begin{array}{l}\text { Pearson Cor- } \\
\text { relation }\end{array}$ & $.630^{* *}$ & $.703^{* *}$ & $.350^{* *}$ & 1 \\
\hline & Sig. (2-tailed) & 0 & 0 & 0.003 & \\
\hline & $\mathrm{N}$ & 70 & 70 & 70 & 70 \\
\hline
\end{tabular}

**. Correlation is significant at the 0.01 level (2-tailed).

\section{Conclusion and Recommendation}

Findings showed that more women participated in agroforestry more than men. In addition more women planted trees and kept livestock compared to men and thus women plays a critical role in agroforestry adoption and adaptation to climate change and variability. The study concluded that residents of Makindu and Nguumo locations had adopted various agroforestry technologies which helped them to adapt to climate change and variability effects.
Women in the area played a critical role in adoption of agroforestry technologies as an adaption strategy to climate change and variability (were able to manage agroforestry technologies) women needed empowerment in various areas which hinder their full participation in agroforestry technologies. Further, study concluded that in Makindu and Nguumo locations agroforestry benefited women in various ways like provision of food, source of various products like fruits, firewood provision, pasture and fodder for livestock, income, and employment. 


\section{Acknowledgement}

The authors are grateful to ministry of Agriculture, Makindu office, chiefs, locations, Sub-chiefs of Nguumo and Makindu household heads for willingly and freely offering information during the study that led to the preparation of this paper.

\section{References}

1. Doss CR (2001) Designing agricultural technology for African women farmers: Lessons from 25 years of experience. World development 29(12): 2075-2092.

2. IFAD (2003) Mainstreaming a gender perspective in IFAD's operation: plan of action 2003-2006. International Fund for Agriculture Development, Rome.

3. World Bank (2007) Gender and economic growth in Kenya: Unleashing the power of women. World Bank.

4. IFPRI (2007) Proceedings of the consultation on strengthening women's control of assets for better development out-comes. IFPRI, Washington DC.

5. Peterman A, Behrman J, Quisumbing A (2010) A review of empirical evidence on gender differences in non-land agricultural inputs, technology and services in developing countries. IFPRI Discussion Paper 00975.

6. Quisumbing A, Pandolfelli L (2010) Promising approaches to address the needs of poor female farmers. World Development 38(4): 581-592.

7. Meinzen-Dick R, Quisumbing A, Behrman J, Biermayr-Jenzano P, Wilde V, et al. (2010) Engendering agricultural research. IFPRI Discussion Paper 00973. Environment and Production Technology Division, IFPRI.

8. Waithanji E, Njuki J, Nabintu B (2013) Gender participation in livestock Markets. In Women, Livestock Ownership and Markets: Bridging the Gap in Eastern and Southern Africa. In: Jemimah Njuki, Pascal Sangi (Eds.), Ottawa, Canada: IRLI and IDRC, p. 40.

9. Tripathi R, Chung YB, Deering K, Saracini N, Willoughby R, et al. (2012) What Works for Women: Proven approaches for empowering women smallholders and achieving food security? Oxfam Policy and Practice: Agriculture, Food and Land 12(1): 113-140.

10. Boserup E (1970) Women's Role in Economic Development.

11. Fortman L (1985) The tree tenure factor in agroforestry with particular reference to Africa. Agroforestry Systems 2: 229-251

12. Rocheleau, Weber F, Juma A (1988) Agroforestry in Dryland Africa. Nairobi: ICRAF.

13. Haddad L, Hoddinott J, Alderman H (1997) Intrahousehold resource allocation in developing countries.

14. Quisumbing AR (1996) Male-female differences in agricultural productivity methodological issues and empirical evidence. World Development 24(10): 1579-1595.

15. Gladwin CH, Thomson MA, Peterson JS, Anderson AS (2001) Addressing food security in Africa via multiple livelihood strategies of women farmers. Food Policy 26(2): 177-207.

16. FAO (2015) Understanding women's participation in forestry in Vietnam. Policy Brief, Thailand.

17. Kiptot E, Franzel S, Degrande A (2014) Gender, agroforestry and food security in Africa. Current Opinion in Environmental Sustainability 6: 104-109.

18. Epaphra E (2001) Assessment of the role of women in agroforestry systems: a case study of Marangu and Mamba in Kilimanjaro region, Tanzania.
19. Gerhardt K, Nemarundwe N (2006) Participatory planting and management of indigenous trees: lessons from Chivi District, Zimbabwe. Agriculture and Human Values 23(2): 231.

20. Franzel SC, Scherr SJ (2002) Trees on the farm: assessing the adoption potential of agroforestry practices in Africa. CABI.

21. Nyeko P, Stewart J, Franzel S, Barkland P (2004) Farmers experiences in the management and utilization of Calliandra calorthyrsus, a fodder shrub in Uganda. Agricultural Research and Extension Network.

22. (2009) Kibwezi community information Centre.

23. Ministry of Agriculture (MoA) (2015) Crop and Livestock Farming annual report in Makindu District.

24. (2009) Census survey in Kenya.

25. (2002) Republic of Kenya. Makindu District Development Plan -2008.

26. Mwangombe AW, Ekaya WN, Muiru WM, Wasonga VO, Mnene WM, et al. (2011) Livelihoods under climate variability and change: an analysis of the adaptive capacity of rural poor to water scarcity in Kenya's dry lands. Journal of Environmental Science and Technology 4(4): 403-410.

27. (2016) Makindu weather base.

28. Nhemachena C, Hassan R (2007) Micro-level analysis of farmers' adaptation to climate change in Southern Africa. IFPRI Discussion Paper No. 00714. International Food Policy Research Institute, Washington, DC

29. Mugure A, Oino PG, Sorre BM (2013) Land Ownership and its Impact on Adoption of Agroforestry Practices among Rural Households in Kenya: A Case of Busia County. International Journal of Innovation and Applied Studies 4(3): 552-559.

30. Charles RM, Munishi PKT, Nzunda EF (2013) Agroforestry as Adaptation Strategy under Climate Change in Mwanga District, Kilimanjaro, Tanzania. International Journal of Environmental Protection 3(11): 29-38.

31. Ludeki JV, Wamukoya GM, Walubengo D (2004) Environmental Management. In: Lundgren BO, Nair PKR (Eds.), (1983) Agroforestry for soil conservation.

32. Scroth G, Sinclair FL (2003) Trees, Crops and Soil Fertility: Concepts and Research Methods. Wallinford, Oxon, U.K: CABI publishers.

33. Fernandes ECM, O'Kingati A, Maghembe J (1984) The Chagga home-gardens: a multi-storied agroforestry cropping system in Mt. Kilimanjaro, N. Tanzania, No. of AF System Description Series, Agroforestry Systems (In Press).

34. International Centre for Research in Agro forestry (1992) A Selection of Useful Trees and shrubs for Kenya. ICRAP, Nairobi, Kenya.

35. Rodenberg B (2009) Climate Change Adaptation from a Gender Perspective.

36. Civil Society Forum of Climate Change (2011) Keadilan Gender dalam Keadilan Iklim. Climate Justice. Jakarta. Commercialization of Gnetum africanum/buchholzianum in Lékié division in Cameroon. Journal of Food.

37. Rakib M, Matz JA (2014) The Impact of Shocks on Gender-differentiated Asset Dynamics in Bangladesh. IFPRI Discussion Paper, (01356). Resources, constraints and interventions. World Development 38(4): 581-592.

38. UN-REDD (2013) UN-REDD Vietnam programme gender analysis. Hanoi UN-REDD.

39. Kiptot E, Franzel S (2012) Gender and agroforestry in Africa: a review of women's participation. Agroforestry systems 84(1): 35-58. 
40. Information Center for Agriclture and Rual Development (ICARD) (2012) Gender equality and the development of agriculture and rural areas. Hanoi, ICARD.

41. McCright AM (2010) The effects of gender on climate change knowledge and concern in the American public. Population and Environment 32(1): 66-87.

42. Safi AS, Smith WJ, Liu Z (2012) Rural Nevada and Climate Change: Vulnerability, Beliefs, and Risk Perception. Risk Analysis 32(6): 10411059.
43. Resurrection BP (2013) Women's Studies International Forum Persistent women and environment linkages in climate change and sustainable development agendas. Women's Studies International Forum 40: 33-43.

44. Farnworth C (2013) Transforming Gender Relations in Agriculture in Sub-Saharan Africa S. I. A. N. Initiative, ed., Stockholm, Sweden. Swedish International Agricultural Network Initiative (SIANI).

Your next submission with Juniper Publishers will reach you the below assets

- Quality Editorial service

- Swift Peer Review

- Reprints availability

- E-prints Service

- Manuscript Podcast for convenient understanding

- Global attainment for your research

- Manuscript accessibility in different formats ( Pdf, E-pub, Full Text, Audio)

- Unceasing customer service

Track the below URL for one-step submission https://juniperpublishers.com/online-submission.php 